\title{
PRESERVATION OF MEGALITHIC SITES AS INTEGRATED TOURISM OBJECTS IN LAHAT REGENCY, SOUTH SUMATRA
}

\author{
Farida R. Wargadalem ${ }^{1}$, A. Siswanto ${ }^{2}$, Ardiansyah $^{2}$, K. Indriastuti ${ }^{3}$ \\ ${ }^{1}$ Department of History Education, Faculty of Teacher Training and Education, \\ Universitas Sriwijaya \\ ${ }^{2}$ Department of Architecture, Faculty of Engineering, Universitas Sriwijaya \\ ${ }^{3}$ Balai Arkeologi Palembang
}

\begin{abstract}
Megalithic sites are a cultural heritage that has the potential to be a tourist attraction. The location of megalithic sites scattered in several subdistricts and mostly located outside the settlement becomes an obstacle to be developed as a tourist destination. The purpose of this research is to develop an integrated tourism strategy that composes megalithic sites, natural attractions, artificial attractions, settlements, and the empowerment of local communities. This research combines historical research and case study. The case study is used by observing the location of megalithic sites in several districts in the Lahat Regency. There are several megalithic sites in the settlement, plantation, or rice fields. Local Communities already have an understanding of utilizing homes as homestays. It is concluded that the determination of zonation in Lahat regency can direct the management of the megalithic site as a tourism object according to the site characteristics and the built environment through community empowerment. The first zoning is the location of megalithic sites on Pagaralam as the direction of tourist arrivals with the village of Gunung Kaya in the Jarai sub-district as the node, and the second zonation on Lahat as the direction of tourist arrivals with the village Sinjar Bulan in Gumay Ulu sub-district as the node. Megalithic site management strategy as an integrated tourist attraction is also carried out by utilizing all the existing potential.
\end{abstract}

Keywords: megalithic sites, management strategies, tourism objects, zoning and community empowerment.

\begin{abstract}
ABSTRAK
Situs megalitik adalah warisan budaya di masa lalu yang berpotensi menjadi objek wisata. Lokasi situs megalitik yang tersebar di beberapa kecamatan dan sebagian besar berada di luar pemukiman menjadi kendala untuk dikembangkan sebagai tujuan wisata. Tujuan dari penelitian ini adalah untuk mengembangkan strategi pariwisata terpadu yang menyusun situs megalitik, atraksi alam, atraksi buatan, permukiman, dan pemberdayaan masyarakat lokal. Penelitian menggunakan dua pendekatan, yakni penelitian historis dan studi kasus. Ada beberapa situs megalitik di pemukiman, perkebunan, atau sawah. Masyarakat setempat sudah memiliki pemahaman tentang pemanfaatan rumah sebagai homestay. Disimpulkan bahwa penentuan zonasi di Kabupaten Lahat dapat mengarahkan pengelolaan situs megalitik sebagai objek wisata sesuai dengan karakteristik situs dan lingkungan binaan melalui pemberdayaan masyarakat. Zonasi pertama adalah lokasi situs megalitik di Pagaralam sebagai arah kedatangan wisatawan dengan desa Gunung Kaya di kecamatan Jarai sebagai simpul, dan zonasi kedua di Lahat sebagai arah kedatangan wisatawan dengan desa Sinjar Bulan di kecamatan Gumay Ulu sebagai simpul. Strategi pengelolaan situs megalitik sebagai objek wisata terpadu juga dilakukan dengan memanfaatkan semua potensi yang ada.
\end{abstract}

Kata kunci: situs megalitik, manajemen, objek wisata, zona, pemberdayaan masyarakat 


\section{INTRODUCTION}

The preservation intended in this paper is the protection of historical sites from change and destruction so that nothing unexpected happens. For this reason, serious efforts must be made so that the valuable historical and cultural heritage can be saved and developed by developing these sites into tourist attractions. This method is quite effective in maintaining and improving historical sites because, through this strategy, preservation efforts become more accessible because of the availability of sufficient funds obtained from tourists who come. Besides, local culture will be developed as well. It will affect other fields, which in turn will improve the welfare of the population. The development of historical tourism and cultural heritage is relevant to the mandate of Law Number 11 the Year 2010 concerning Cultural Heritage. It which states that cultural heritage is "representing the nation's cultural wealth as an expression of thought and behavior of human life which is important for the understanding and development of history, science knowledge, and culture in the life of society, nation and state, so it needs to be preserved." One of the ways to preserve is to develop cultural heritage as a tourism object. The world organization WTO (UNWTO) states that cultural tourism is currently very fast-growing because it has become the most significant global tourism market reaching forty percent. The tourists are more interested in historical locations, traditions, culture, comfortable places, places that have a relationship with local or national or even international figures. Furthermore, the 2012 UNWTO states that cultural tourism (cultural tourism) is a trip that focuses on visiting historical sites, which have been transformed into the cultural heritage of supporting communities (Pedoman Pengembangan Asisten Deputi Pengembangan Wisata Budaya, 2018).

Blending history and culture with tourism has been carried out by nations in the world, which are known for having many cultural heritages, such as China and Egypt. These two countries are con- crete examples in the development of the tourism sector by relying on cultural heritage as a tourist attraction, supported by other industries, such as beauty and natural wealth. Since 1963, the United Nations (UN) in the economic and social fields has declared that cultural heritage is used as a tourist attraction. Cultural heritage has scarcity and history that is the identity of the supporting community. Automatic recognition of cultural heritage in the form of historical sites and other cultures will enrich the experience of priceless tourists so that it will have a kind of "advertising" to encourage people (friends, family, colleagues, and others) to do the same thing. More and more people going on a tour means it will have an impact on economic development in all fields, including an increase in the preservation of cultural heritage (Adiatama, 2018, pp. 26-27).

UNESCO (2009) states that the World Tourism Organization (WTO) has determined that what is meant by heritage tourism is an activity intended to enjoy history, cultural heritage, institutions, philosophy, art, and nature. Meanwhile, currently, there is a tendency to travel to both individuals and groups to travel in order to expand knowledge. Others take business trips/work while going, known as "bleisure trips" (business + leisure). This form is becoming a trend because it is increasingly difficult for people to be busy looking for a particular time for a vacation. Besides, another trend that is on the rise is that travel is no longer just visiting crowded places that are already famous, and shopping, but they are more interested in visiting sites that are "more valuable." They travel to a place to gain knowledge and experience that is different and valuable, namely in the traditions, history, and local culture, as well as interacting with the community, even not infrequently sharing the activities carried out by the people they visit. They want to feel something other than what they usually do, out of routine. Now, it has also begun to favor environmentally friendly tourism, namely eco-tourism. Often, they are not reluctant to search for a natural location 
that is still maintained its authenticity with the culture of the supporting community.

Further examples will be given linking historical and cultural tourism, namely the Province of Aceh. In the province, there have been significant changes in tourism since the 2004 tsunami, and the signing of the Helsinki Memorandum of Understanding $(\mathrm{MoU})$ marked the end of the ongoing conflict in Aceh on August 15, 2005. It made Aceh entering a new era of openness towards tourism development based on sharia. So that Aceh became one of the halal tourism destinations in Indonesia. Aceh also received the World's Best Halal Cultural Destination in Abu Dhabi in the "World Halal Tourism Award." The most favorite tourist attraction is historical tourism consisting of the Baiturrahman Grand Mosque, the Aceh Tsunami Museum and Kherkoff, Ships above the House, the Floating PLTD Museum, Sari Gunongan Park, Lhoknga beach and Lampuuk Beach. From these various attractions, it seems clear that historical tourism occupies the highest position. Besides, Aceh, as the "Veranda of Mecca," is indeed loaded with historical and religious tourism. The development of historical tourism has both positive and negative impacts on the area. An example is the growing economy of the community, thereby increasing the welfare of society in general. Also, efforts to preserve local culture (traditions, customs), historical sites, and protect the natural environment are encouraged.

The community is also more open to accepting national and foreign tourists. Even so, there are also adverse effects, such as conflicts between fellow stakeholders there. There is still a rejection towards the development of tourism, as well as other harmful excesses in the form and emergence of social problems such as gambling practices, sexual abuse (sexual abuse), and prostitution. The Aceh government is trying to eliminate the negative impact by tightening the implementation of Qanun No. 14 of 2003, followed by the issuance of Law No. 11 of 2006, and the fatwa of the ulemas that had been decided in the Aceh Ulema Consultative Assembly. All that to eliminate the negative impacts of tourism. (Swesti, 2019, pp 50-53, p. 55). Nevertheless, Aceh has proven to have succeeded in increasing the welfare of its population through tourism. Aceh Tourism is mostly in the form of historical tourism, integrated with nature and culinary tourism.

The city of Palembang can also be used as the next example relating to making use of historical relics that are tourism objects. The establishment of Palembang cannot release it as part of the Indonesian Heritage City Network (JKPI) since October 2018. It means that Palembang has a high historical and cultural value. Based on quantitative studies using variables, "the authenticity of the historical landscape (the shape of the building and land use), the attraction of historical tourism (historical associations, scarcity, integrity, and aesthetic quality), and ease of accessibility." Based on these categories, the conclusion that can be drawn is Tengkurap Crater, and Kapitan Village are in a low category. The category is the Tomb of Ki Gede Ing Suro, Sultan Mahmud Badaruddin II Museum, and Assegaf Village. High categories are the Kingdom of Sriwijaya Archaeological Park, Ampera Bridge, Benteng Kuto Besak, Kampung AlMunawar, and Bukit Siguntang. (Sukmaratri, 2018: pp. 165-166, p. 172). The historical sites in the city of Palembang that are still visible, while those that have been lost, either intentionally or unintentionally due to ignorance, are quite a lot or even a lot if counted from the time of the Srivijaya Kingdom until now. From these studies, there is a close correlation between categories and the number of tourist visits. The higher the category, there appear to be more tourists, and historical sites have a great potential in attracting tourists to come to the city of $\mathrm{Pa}$ lembang. In this study, we will try to look further at Megalithic site management strategies that are linked to other tourism objects in the district.

In addition to megalithic sites, the 
mainstay of tourism in the Lahat Regency are natural attractions such as waterfalls and rafting, cultural tourism such as dances, traditional marriages, culinary and traditional houses, and artificial tours such as parks and suspension bridges. As a tourist attraction, megalithic sites are only able to attract a few tourists, especially those who have special interests. It is understandable because some people think that megalithic sites are piles of stones from the past (Irwanto, 2011). On the other hand, accessibility to megalithic sites is relatively far and steep. The tourism potential in Lahat Regency, which is more visited by tourists is waterfall and rafting, which is very numerous with the main icon of Dempo Mountain and Bukit Tunjuk.

Most of the megalithic sites are located in the middle of rice fields and coffee, rubber, cocoa, and horticultural plantations situated far from residential areas (Astiti, 2017). Some other megalithic sites are located near residential settlements and on the edge of the main road. Furthermore, local people do not understand that these megalithic sites can be used indirectly as relics of the past that must be preserved.

Some of the past relics found in Lahat district are old settlements that still have old baghi houses, traditional houses of the Besemah tribe, ethnic groups living in Lahat and Pagaralam districts. Several megalithic sites are located adjacent to traditional settlements and Baghi houses. Although it is close to the location of residential areas, local people do not understand the meaning of megalithic sites as objects of cultural heritage related to their history and environment

Based on the existing conditions, the main direction of tourist visiting is from Lahat and Pagaralam, so these two points are important considerations for developing zoning and tourist destinations in Lahat Regency. In its development, the promising natural tourism potential has been able to be utilized by travel agents and hotels to create tour packages with destinations to various natural attractions and megalithic sites, especially those close to the main road.

The potential of this sizeable megalithic site can be an asset to develop tourism in Lahat Regency. At present, the tendency to travel for both individuals and groups is carried out to expand knowledge. Others go on business trips/ work while traveling, known as "bleisure trips" (business + leisure). This group is becoming a trend because it is difficult for busy men to look for a particular time for a vacation. Besides, another direction that travels is no longer just visiting famous crowded places and shopping, but they are more interested in visiting more valuable areas. They go to a place to get different and relevant knowledge and experience. This group is interested in local traditions and culture, as well as interacting with the community, often even participating in the activities of the people they visit. They want to feel something other than what they usually do, out of routine. Now, it has begun to favor environmentally friendly tourism, namely eco-tourism. Often, they are not reluctant to look for a natural location that is still maintained its authenticity with the culture of the supporting community.

Based on the above problems, this study aims to develop a Megalithic Site Management Strategy as an Integrated Tourism Object in Lahat Regency. Management of megalithic sites is designed in an integrated manner with the potential for natural, cultural, and human-made tourism through the empowerment of local communities. Thus it is hoped that community participation living around the site can improve the local economy along with efforts to preserve better megalithic sites.

\section{RESEARCH METHOD}

This research combines historical research and case study. First, as historical research, the method derived in four stages, namely heuristics, source criticism, source interpretation, and reconstruction (Notosusanto, 1978, pp. 11-12). The first step is gathering relevant data. In this section, what is done is to study journals that 
discuss the Pasemah megaliths that have been discovered since the beginning of the 20th century. In addition, books are also presented on this topic, as well as the results of reports conducted by the Palembang Archeology Center, which is concerned with researching from its archaeological aspects. Data collection is also carried out by field study, to obtain direct data, as well as conducting interviews with communities around megalithic sites. Next is to critique the data that has been obtained. Existing data are sorted both internally and externally to see originality (field data, and preliminary journals discussing Pasemah megaliths, as well as books used), authenticity (data authenticity), credibility (trustworthiness) and integrity (completeness of data). Besides, criticisms of the level of relevance to the theme taken were also carried out. The next step is to interpret. That is, the data that has been completed has been criticized will be interpreted in an effort to interpret what is contained in the data. This meaning is called a historical fact. Finally, reconstruction is carried out by assembling facts after facts separately to produce scientific history.

The case study used by observing the location of megalithic sites in several districts in Lahat Regency.

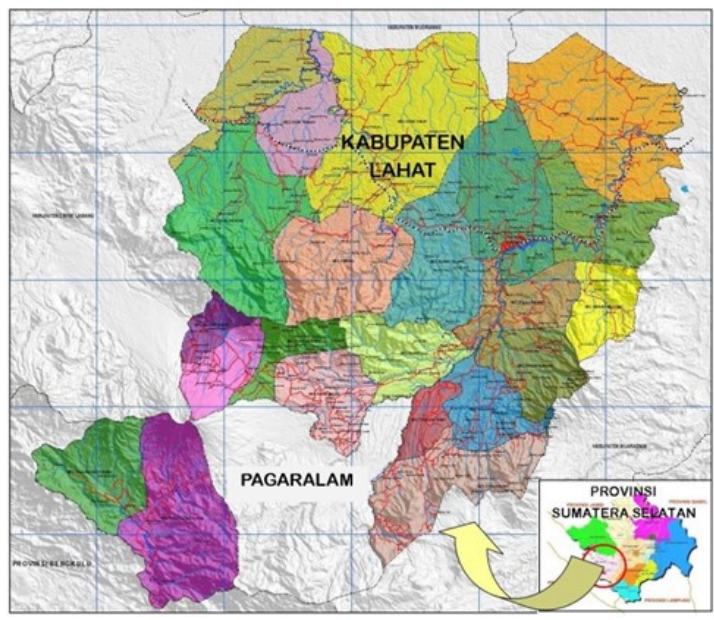

Figure 1. Map of Lahat Regency, surrounding the city of Pagaralam

The location of megalithic sites is associated with natural and cultural tourism ob- jects and traditional settlements and houses as a whole. Secondary data collection was based on previous research, informant information, and related literature. Furthermore, primary data were obtained through field observations and interviews with respondents directly. Respondents who have competencies following the objectives of this study include bureaucrats, community leaders, tour operators, archeologists, site keepers, and the community who lives around the site location. The scatter of site locations and megalithic uniqueness, as well as potential tourism objects and traditional settlements, were analyzed to determine to zone based on the direction of tourist arrivals from the city of Lahat or Pagaralam. Next, a node for a megalithic site or settlement from zoning was determined. A focus group discussion (FGD) activity was also carried out involving stakeholders such as the head of the district, the village leader, village officials, community leaders, site keepers, house owners, homemakers, and youth organizations.

\section{RESULTS AND DISCUSSION Megalithic Site in Lahat Regency}

The administrative area of Lahat district is $4,361.83 \mathrm{~km} 2$, consisting of $22 \mathrm{sub}$ districts, 17 villages, and 359 villages. (Lahat Regency Culture and Tourism Office, 2016). Geographically Lahat Regency in South Sumatra Province is located at $3,25^{0}$ to $4,15^{\circ}$ South Latitude and $102,37^{\circ}$ to $103,45^{\circ}$ East Longitude. Regency boundary covers in the North with Muara Enim and Musi Rawas districts. In the south with the city of Pagar Alam and Bengkulu Selatan regency, Bengkulu province. In the east with Muara Enim regency. In the west with Empat Lawang regency.

Based on previous research, in the Pasemah / Besemah area, there were found many megalithic relics in an extensive area. Chronologically, artifacts of megalithic sites in the Besemah area was reported by Ullman in 1850, Tombrink in 1870, Engelhard in 1891, Chrome in 1918, Westernenk in 1922, and Hoven in 1927. 


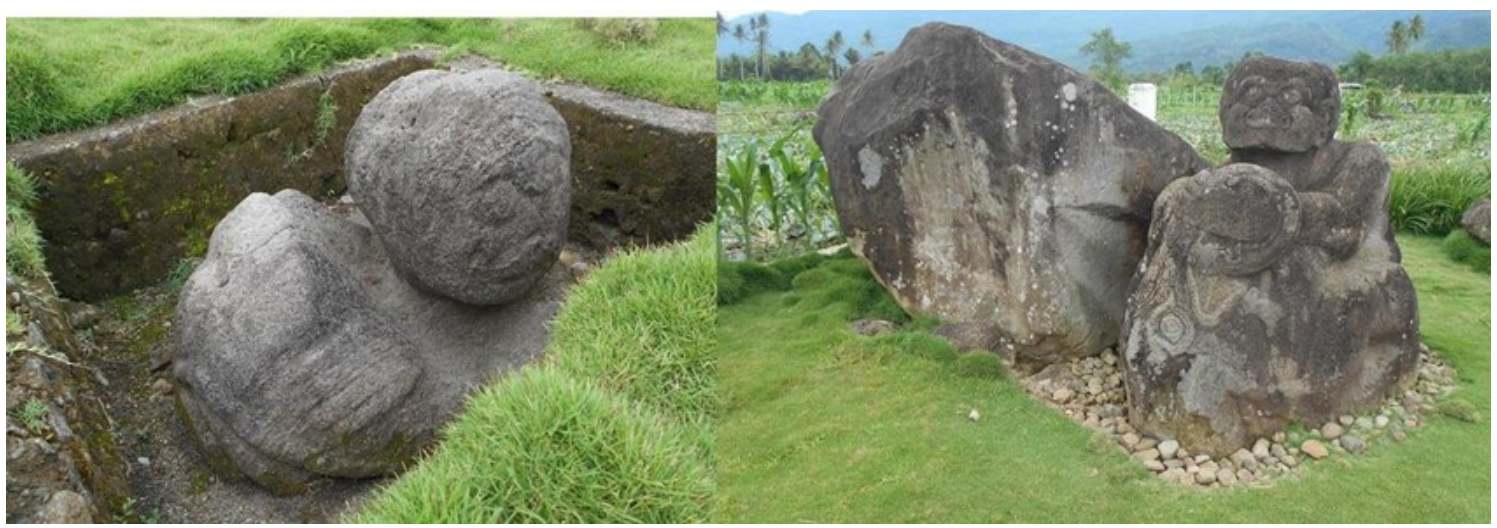

Figure 2. Unique Megalithic site in Gunung Megang village, Jarai district which can be used as a tourist attraction

Almost all assume that megalithic sites were a relic of Hinduism. Further developments when van Eerde in 1929 visited the site, he had a different opinion than the megalithic site in Besemah was not influenced by Hindu (Suryanegara, 2017) culture, but was still within prehistoric reach. Megalithic site forms on relics such as the menhirs, dolmen, and human statues.

Furthermore, van der Hoop carried out further in-depth research for approximately seven months in Tanah Besemah and published in a complete report about the megalithic sites in that area. This publication is still a valuable reference for research on megalithic sites in Tanah Besemah. Van Heerkeren has made an overview of the discoveries of megalithic sites in Indonesia, including in South Sumatra. At the same time, Peacock tried to discuss the Besemah megalithic from a different side, namely, from the historical aspects and its function to provide a picture of social life in the past.

The results of archaeological studies confirm that in Tanah Besemah there was a community that lived and developed in the prehistoric trajectory and could describe the lives of prehistoric societies. It proved that many relics of megalithic culture scattered, for example, in Mount Kaya, Kota Raya Lembak, Mount Megang, Pulau Panggung, Geramat, and so on (Suryanegara, 2016). In some of these sites, stone tombs or stone cubes painted or scratched and formed from large stones used as walls and roofs (Indriastuti, 2015).
The rocks were arranged in a hole prepared before.

Iksan (2004) states that megalithic sites in Lahat Regency are the very potential to be developed as cultural tourism objects (figure 2). In his study, it was noted that transportation facilities became a critical obstacle instead of a lack of promotion so that megalithic sites were not yet widely known or visited by tourists from outside the Regency.

In recent decades, many archaeological studies have been carried out, and other more in-depth studies of megalithic sites. However, in the last five years, there are still found locations of megalithic sites and archaeological remains (Wurjani, 2011 and Sudaryadi, 2016).

Wiyana (1996) and Irwanto (2011) explain the relationship between the location of megalithic sites and the opportunities for economic patterns of the local community that could be developed to support the tourism sector in Lahat district. Furthermore, Triwurjani (2014) describes the megalithic sites in Lahat Regency in the semiotic field. It offers a new perspective in interpreting megalithic sites not only as objects of cultural heritage but also about meaning and symbols. This study provided an overview of the possibility of making compelling narratives from megalithic sites based on the symbols contained in these sites to broaden insight and understanding of the existence of megalithic sites. 


\begin{tabular}{|c|c|c|c|c|c|c|c|c|c|c|c|c|c|c|c|c|c|c|}
\hline \multirow[b]{2}{*}{ No } & \multirow[b]{2}{*}{ District/Village } & \multicolumn{17}{|c|}{ Megalithic Types } \\
\hline & & 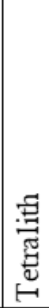 & 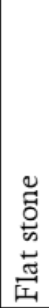 & 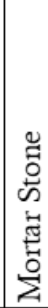 & 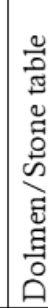 & 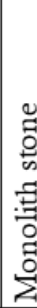 & 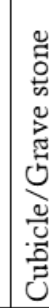 & 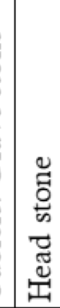 & 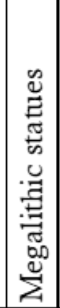 & 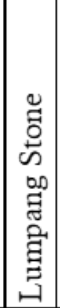 & 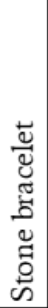 & : & 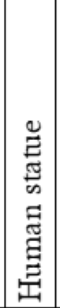 & 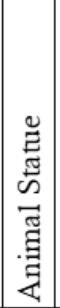 & 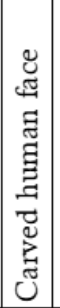 & 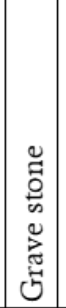 & 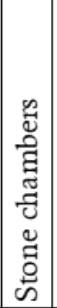 & 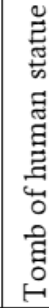 \\
\hline 1 & PAJAR BULAN & & & & & & & & & & & & & & & & & \\
\hline 1.1 & Desa Sumur & $\sqrt{ }$ & $\sqrt{ }$ & $\sqrt{ }$ & $\sqrt{ }$ & $\sqrt{ }$ & & & & & & & & & & & & \\
\hline 1.2 & Desa Pajar Bulan & $\sqrt{ }$ & $\sqrt{ }$ & & $\sqrt{ }$ & $\sqrt{ }$ & & & & & & & & & & & & \\
\hline 1.3 & Desa Kota Raya, Lembak & $\sqrt{ }$ & & $\sqrt{ }$ & $\sqrt{ }$ & & $\sqrt{ }$ & & & & & & & & & & & \\
\hline 1.4 & Desa Talang Pagar Agung & & & & $\sqrt{V}$ & & $\sqrt{ }$ & $\sqrt{ }$ & & & & & & & & & & \\
\hline 1.5 & Desa Pulau Panggung & $\sqrt{ }$ & $\sqrt{ }$ & $\sqrt{ }$ & & & & & $\sqrt{ }$ & $\sqrt{ }$ & & & & & & & & \\
\hline 2 & JARAI & & & & & & & & & & & & & & & & & \\
\hline 2.1 & Desa Sawah Jemaring & $\sqrt{ }$ & $\sqrt{ }$ & $\sqrt{ }$ & $\sqrt{ }$ & & & & & & & & & & & & & \\
\hline 2.2 & Desa Muara Tawi & & & & $\sqrt{ }$ & & & & & & & & & & & & & \\
\hline 2.3 & Desa Gunung Megang & $\sqrt{ }$ & & $\sqrt{ }$ & $\sqrt{ }$ & $\sqrt{ }$ & & & $\sqrt{ }$ & $\sqrt{ }$ & & & & & & & & \\
\hline 2.4 & Desa Gunung Kaya & $\sqrt{ }$ & $\sqrt{ }$ & $\sqrt{ }$ & $\sqrt{ }$ & & & & & & & & & & & & & \\
\hline 2.5 & Desa Pagar Dewa & & & & & & & & & & $\sqrt{ }$ & & & & & & & \\
\hline 3 & PULAU PINANG & & & & & & & & & & & & & & & & & \\
\hline 3.1 & Desa Rindu Hati & & $\sqrt{ }$ & $\sqrt{ }$ & $\sqrt{ }$ & & & & $\sqrt{ }$ & & & & & & & & & \\
\hline 3.2 & Desa Tinggi Hari 1 & & & $\sqrt{ }$ & & & & & $\sqrt{ }$ & & & $\sqrt{ }$ & & & & & & \\
\hline 3.3 & Desa Tinggi Hari 2 & & $\sqrt{ }$ & & & & & & $\sqrt{ }$ & $\sqrt{ }$ & & $\sqrt{ }$ & & & & & & \\
\hline 3.4 & Desa Tinggi Hari 3 & $\sqrt{ }$ & $\sqrt{ }$ & & & & & & $\sqrt{ }$ & & & $\sqrt{ }$ & & & & & & \\
\hline 3.5 & Desa Tinggi Hari 4 & $\sqrt{ }$ & $\sqrt{ }$ & $\sqrt{ }$ & $\sqrt{ }$ & & & & $\sqrt{ }$ & $\sqrt{ }$ & & & & & & & & \\
\hline 3.6 & Desa Tanjung Sirih & $\sqrt{ }$ & $\sqrt{ }$ & $\sqrt{ }$ & $\sqrt{ }$ & & & & $\sqrt{ }$ & $\sqrt{ }$ & & & & & & & & \\
\hline 3.7 & Desa Karang Dalam & & & & $\sqrt{ }$ & & & & & & & $\sqrt{ }$ & $\sqrt{ }$ & & & & & \\
\hline 4 & MULAK ULU & & & & & & & & & & & & & & & & & \\
\hline 4.1 & Desa Muara Danau & & $\sqrt{ }$ & & $\sqrt{ }$ & & & & $\sqrt{ }$ & & & $\sqrt{ }$ & & & & & & \\
\hline 4.2 & Desa Rindu Hati & & & $\sqrt{ }$ & $\sqrt{ }$ & & & & $\sqrt{ }$ & & & & & & & & & \\
\hline 4.3 & Desa Geramat & $\sqrt{ }$ & & $\sqrt{ }$ & & & & & & & & & $\sqrt{ }$ & $\sqrt{ }$ & & & & \\
\hline 5 & TANJUNG TEBAT & & & & & & & & & & & & & & & & & \\
\hline 5.1 & Desa Tanjung Menang & & $\sqrt{ }$ & & & & & & & & & $\sqrt{ }$ & & & $\sqrt{ }$ & & & $\sqrt{ }$ \\
\hline 5.2 & Desa Negeri Celeng/Talang Gardu & & $\sqrt{ }$ & $\sqrt{ }$ & & & & & $\sqrt{ }$ & $\sqrt{ }$ & & & & & & & & \\
\hline 6 & PAGAR GUNUNG & & & & & & & & & & & & & & & & & \\
\hline 6.1 & Desa Lesung Batu & & & $\sqrt{ }$ & $\sqrt{ }$ & & & & & & & $\sqrt{ }$ & & & & & & \\
\hline 6.2 & Desa Air Lingkar & & & $\sqrt{ }$ & & & & & & & & $\sqrt{ }$ & & & & & & \\
\hline 6.3 & Desa Pagaralam/ Pagar Gunung & & $\sqrt{ }$ & $\sqrt{ }$ & $\sqrt{ }$ & & & & & & & & & $\sqrt{ }$ & & & & \\
\hline 7 & GUMAY ULU & & & & & & & & & & & & & & & & & \\
\hline 7.1 & Desa Sinjar Bulan & & & $\sqrt{ }$ & $\sqrt{ }$ & & & & $\sqrt{ }$ & & & & & & & & & \\
\hline 7.2 & Desa Tanjung Raja & & $\sqrt{ }$ & $\sqrt{ }$ & & & & & $\sqrt{ }$ & & & & & & & & & \\
\hline 7.3 & Desa Muara Dua & & $\sqrt{ }$ & $\sqrt{ }$ & & & & & $\sqrt{ }$ & & & & & & & & & \\
\hline 7.4 & Desa Rindu Hati & $\sqrt{ }$ & & & $\sqrt{ }$ & & & & $\sqrt{ }$ & & & & & & & & & \\
\hline 8 & KOTO AGUNG & & & & & & & & & & & & & & & & & \\
\hline 8.1 & Desa Tanjung Beringin & & $\sqrt{ }$ & & & & & & $\sqrt{ }$ & & & & & & & & & \\
\hline 9 & MERAPI BARAT & & & & & & & & & & & & & & & & & \\
\hline 9.1 & Desa Tanjung Telang & & & $\sqrt{ }$ & & & & & $\sqrt{ }$ & & & & & & & & & \\
\hline 10 & MUARA PAYANG & & & & & & & & & & & & & & & & & \\
\hline 10.1 & Desa Muara Payang & & & & & & & & & & & & & & & $\sqrt{ }$ & & \\
\hline 10.2 & Lawang Agung & & & & & & & & & & & & & & & & $\sqrt{ }$ & \\
\hline
\end{tabular}

Figure 3. The Potential Megalithic Sites in Lahat district 


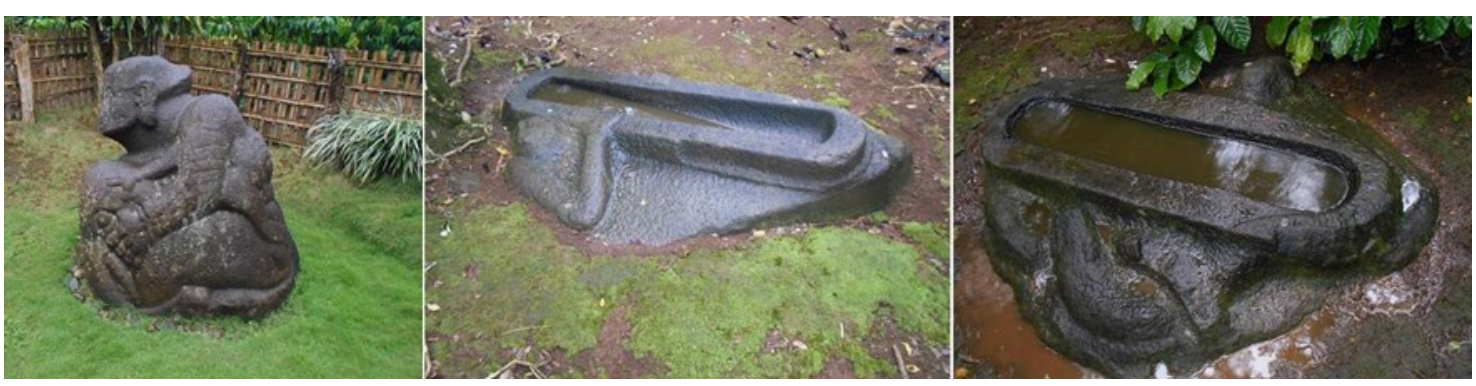

Figure 4: Megalithic sites in Pulau Panggung village, Pajar Bulan sub-district.

Megalithic sites in the village of Gunung Megang (picture 3) are located in several locations in the middle of the community coffee plantations. This site location is about $1 \mathrm{~km}$ to $1.5 \mathrm{~km}$ from local community settlements.

\section{Tourism Potential in Lahat Regency}

The potential of extraordinary and unusual megalithic sites, natural and artificial objects, as well as culture and houses, can support tourism activities in Lahat district by considering current tourism trends. This opportunity can be utilized for the preservation and development of integrated megalithic sites as potential tourism objects and destinations in Lahat district. The development of tourism contributes significantly to the welfare of the population (Astiti, 2017). The development of tourism needs synergy between the government and its supporting communities while preventing the adverse effects caused by these activities, such as environmental damage, and historical sites that are assets of the area. (Yoeti, 2008).

Various needs and interests of tourists in conducting tourist trips are found in different objects in Lahat Regency, for example, beautiful scenery of nature, regional cultural arts, historical heritage, various local wisdom, and traditions, as well as outdoor adventures. Those are exciting combinations, which are worth developing. The regency is located in a highland area, with mountain valleys, and an aesthetic selling point called "megalithic." Megalithic locations in Lahat Regency are in the middle, or not far from residential areas. In the area of coffee, cocoa and hor- ticultural plantations, rice fields with beautiful views of Mount Dempo and Bukit Barisan.

The condition of the Megalithic sites in the Regency has scattered over ten subdistricts, most of which are located far apart in a well-maintained and or imperfect condition. Also, supporting facilities and infrastructure for megalithic sites are still lacking. These problems include the lack of community involvement in supporting the object/site to be developed, the lack of utilization of the natural environment so that it becomes a united tourist visiting area that can be glimpsed by everyone from various local, national, and even international regions. Existing sites need to be arranged integrated as a whole so that development can be directed, sustainable, and provide a significant contribution to the welfare of society. If natural resources are exploited, it will be exhausted, but on the other hand, cultural products will be even more significant when it is explored and developed.

In Lahat district, the distribution of sites and the direction of tourist arrivals are the primary considerations for determining the zone of megalithic sites. The planning consists of the grouping of site locations through the analysis of the scatter of megalithic sites and tourism objects in the area, also, the accessibility from Lahat and Pagaralam. And the participation of people living near megalithic sites. In general, natural attractions such as waterfalls and rafting are more attractive to tourists compared to megalithic sites. Therefore, megalithic sites must be linked to natural attractions to attract the atten- 
tion of tourists. In terms of the direction of tourist arrivals, Lahat is a consideration because it is crossed by the Central Sumatra Road (Lampung-Medan). At the same time, Pagaralam, which is surrounded by the Lahat district area, is an essential element because it has airports for Jakarta, Bandar Lampung, and Palembang destination.

Therefore, zoning can illustrate the relationship between the grouping of Megalithic sites in Lahat district with other tourism objects, infrastructure, and the potential of surrounding communities that have relatively close accessibility to Lahat or Pagaralam (figure 4). Lahat and $\mathrm{Pa}$ garalam, based on national policies for regional development, are the local growth centers in the province of South Sumatra. Two zoning areas of megalithic sites that can be energized with natural, artificial, and cultural tourism objects, as well as settlements that lead to two growth centers, are Lahat city and Pagaralam city. Some sub-districts such as Merapi Barat, Gumay Ulu, Pulau Pinang, Pagar Agung, and Mulak Ulu are oriented towards Lahat city because of their proximity and accessibility. Even though it is part of the Lahat Regency, several sub-districts that have megalithic sites such as Jarai, Pajar Bulan, Muara Payang, Tanjung Tebat, Kota Agung and Suka Merindu are oriented towards Pagaralam. It is because

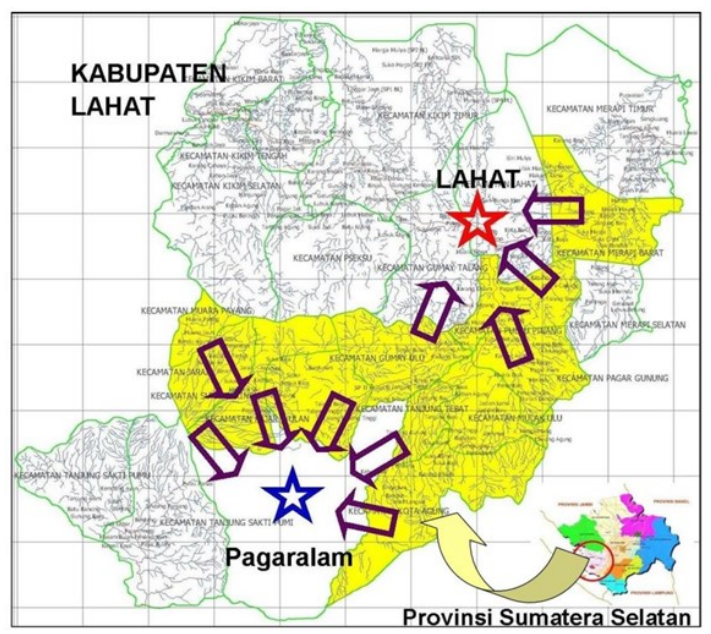

Figure 5. Determination of zoning based on orientation towards the growth center and tourist arrivals of proximity and accessibility becomes beneficial factors. (Dhiniati and Mardiansyah, 2016).

Based on zoning, megalithic sites in Lahat Regency can be one of the attractions of tourist destinations to be complement attractions such as waterfalls, rafting, and mountain panorama in a tour package. Easily accessible sites will have more visitors than those too far away. The distance factor and the level of difficulty affect the costs incurred by tourists who will come to the megalithic sites in this district. To find it regards the individual travel cost method. This study measured the level of personal visits to the costs incurred by these tourist attractions. It can be seen the frequency of tourist arrivals in a specific time at one of the Lahat megalithic sites and can be compared with other sites.

Besides, the demand for tourism is also closely related to the combination of services existing in these tourist attractions (Schmoll, 1977). In megalithic sites, in addition to good access, services as well as the attention of the people around the site. Sometimes the surrounding community only sells makeshift items such as drinking water and instant noodles, even though there is potential from the food sector that can be developed from their area, including residents' homes as homestays (Dewi, 2013).

Based on observations, interviews, and analysis, it has been determined for the first zonation oriented to the city of Lahat. The primary node is Sinjar Bulan village in Gumay Ulu sub-district, while the second zonation adapted to Pagaralam city is mainly Gunung Kaya village in Jarai sub-district. Determination of the two villages as nodes with consideration, first, the Sinjar Bulan site is located not too far from the capital city of Lahat Regency and is only one kilometer from the Gumay Ulu sub-district office, so that it is easily accessible. This site has several advantages, namely its megalithic site has been maintained and developed, located not far from the Wildlife Reserve area, Selais river, which is the location of raft- 


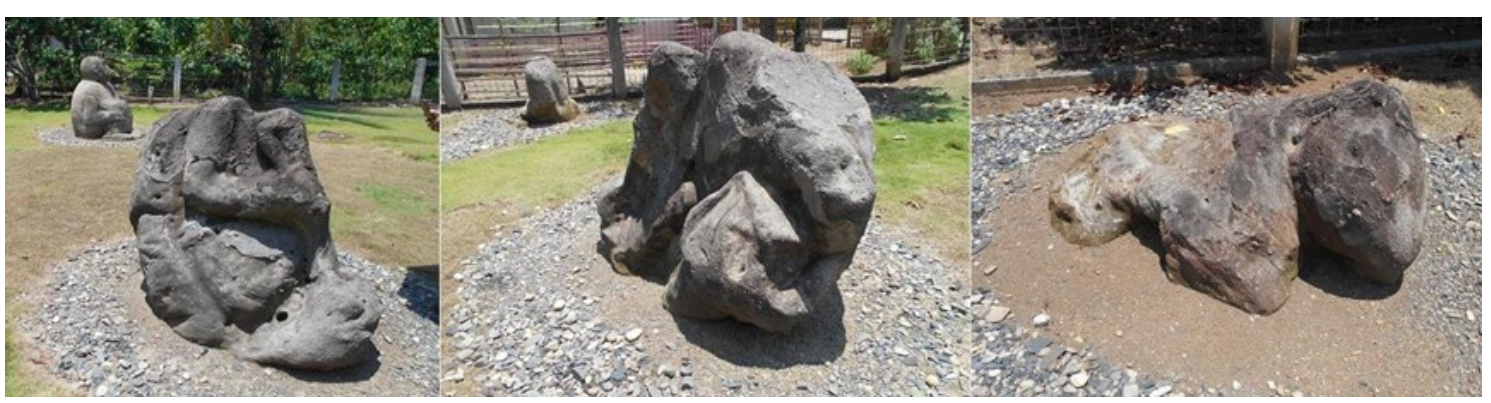

Figure 6. Megalithic site in Sinjar Bulan village, Gumay Ulu district

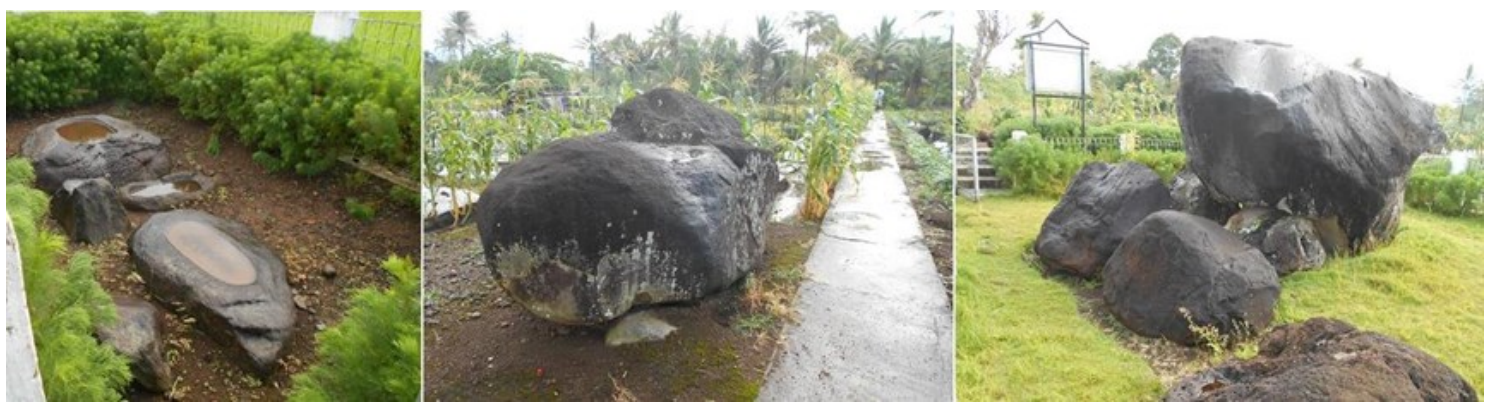

Figure 7. Megalithic site in Gunung Kaya village, Jarai district

ing, waterfalls (cughup), and coffee plantations.

Gunung Kaya village was chosen because the megalithic relics are located in the middle of a horticultural garden. And it close to residential areas (figure 6). They are organized and neat, making it suitable to be a homestay for tourists visiting there. Also, near the megalithic location, there are waterfalls and tebat. Determination of zoning from megalithic sites is an effort so that the area of cultural heritage can be more secure through the empowerment of local communities because they can benefit economically in the context of managing the site as a tourist and cultural heritage area.

\section{Megalithic site management strategy as a preservation effort through community empowerment}

According to UNESCO (2009), tourism is a temporary travel activity, not to settle or to find work, solely for stimulating activities. Thus, tourism is a "pleasant job" in any place, which is not to settle permanently. Related to archeological sites as tourism objects rely on ideological, academic, and economic interests. This concept has embedded in Law No. 11 the year 2010, concerning Cultural Heritage, Chapter VII Article 85 Paragraph 1 "The Government, Regional Government, and anyone can utilize the Cultural Heritage for religious, social, educational, scientific, cultural technology and tourism interests. Paragraph (4) promotion, as referred to in paragraph (2) is conducted to strengthen cultural identity and improve the quality of life and income of the community."

Cultural tourism is a tourism activity based on the understanding of culture as the wealth of the past or a protected area that has monuments, historical sites, architects, or artifacts (Ardiwidjaya, 2008). Cultural tourism activities are a trip to increase appreciation and knowledge of cultural heritage related to aspects of social and cultural life. Furthermore, tourism objects are not only based on monuments, historical sites, and artifacts but also include local arts and traditional ceremonies, which are packaged in the form of cultural festivals. The development of archeological sites as a tourist attraction for cultural resources in the form of tangible (archeological remains) and intangible cultures (community traditions, and traditional ceremonies) can be packaged into 
cultural festivals. Cultural tourism is more appropriate if it is categorized as tourism based on various forms of activities related to the utilization of cultural heritage (including archeological remains).

Empowerment in this research is an effort to create a community group to be able to develop their strengths or abilities, through their active role to fill tourism activities that are integrated with the preservation and development of megaliths, and the natural surroundings. Thus, community empowerment is a process of developing human resources themselves, in the form of exploring personal abilities, creativity, competencies, and thinking power and actions better than before. Community empowerment is essential, and it is mandatory to do to concerning rapid economic and technological growth lately.

Community empowerment activities are carried out to provide an understanding that megalithic sites are inherited from ancestors that need to be preserved, and can be utilized for the economic events of local communities. Communities are given an understanding that they have assets, and the potential that can be developed to take advantage of opportunities for developing tourism activities in Lahat and Pagaralam districts (Dewi, 2013). Their settlements and homes can be designed as homestays for tourists who want to feel the calm rural atmosphere with beautiful views. Welcoming attitude and social ethics to greet guests are the main factors of success in attracting tourists to come and stay in their village (Susyanti, 2014 and Astiti, 2017).

Essential requirements as a homestay are clean bathrooms, sufficient freshwater, and a healthy home. Another critical factor is the presentation of unique, delicious, and exciting local cuisine and well served. The response of the community in Gunung Kaya village was very positive, and the community was willing to seize the opportunity, ready to make their home a homestay. These activities can be carried out as work or parttime actions that do not take up much time. Community empowerment was carried out through focus group discussion (FGD) activities, participants consisting of sub-district and village officials, site keepers, homeowners who are willing to take part in a homestay program. The mothers who are members of the dasa wisma group, and youth Cadets Community (Dhiniati and Mardiansyah, 2016). In this activity, an organizational structure called "Sehepat-Sehendi" was formed, which was managed by the local community. Organizations aim to open homestays in their villages and serve the needs of tourists (domestic and foreign). Some homeowners expressed their willingness and agreement to make their homes as homestay and providing food while the youth community prepared themselves as tour guides located around the homestay.

\section{CONCLUSION}

Lahat Regency, the center of megaliths in South Sumatra, has the potential to be developed as an integrated tourism object with natural attractions and cultural tourism to have a positive impact on the surrounding community in the form of economic improvement, and concern for the preservation of megalithic sites. Tourists visit megalithic sites can be enhanced with better accessibility support, considering the direction of tourist arrivals from Lahat or Pagaralam and determining to zone to facilitate tourist visits. The megalithic site grouping produces two zonations, each of which is oriented to Lahat and Pagaralam. Each zonation has a node, namely Sinjar Bulan village in Gumay Ulu district, which is adapted to Lahat and Gunung Kaya village in Jarai district, which is oriented towards Pagaralam.

Community empowerment activities through focus group discussions have resulted in the community's willingness to use their homes as homestays and selfmanage through community-run organizations. Positive responses from the community of Gunung Kaya village were manifested in the form of establishing a "tourist greeter" organization with the name "Sehepat-Sehendi." This organization will 
later become a driving force in dealing with everything related to the development of tourism in their area, with a knot called megalithic. Homestay is expected to increase the economic activities of the community in addition to increasing community awareness to preserve and maintain the megalithic sites around their settlements.

\section{REFERENCES}

Adiatama, D. (2018). Pengembangan Produk Wisata Heritage Situs Megalitik Gunung Padang. Tourism Scientifie Journal, 4(1).

Anonymous. (2018). Pedoman Pengembangan Asisten Deputi Pengembangan Wisata Budaya. In Eperformance Kemenpar RI. Retrieved April 4, 2020, from http:// eperformance.kemenpar.go.id/ dokumen/.

Ardiwijaya. R. (2008). Pariwisata Budaya sebagai Salah Satu Alat Pelestarian Kesenian Tradisional. In Academia. Retrieved April 1, 2020, from https:// www.academia.edu/.

Astiti, N. K. A. (2017). Kawasan Kompleks Bangunan Megalitik di Kabupaten Lahat sebagai Daya Tarik Wisata Budaya dan Alam. Kapata Arkeologi, 13(2), 195208.

Dewi, M. H. U. (2013). Pengembangan Desa Wisata Berbasis Partisipasi Masyarakat Lokal di Desa Wisata Jatiluwih Tabanan, Bali. Kawistara, 12(1), 117-226.

Dhiniati, F. and Mardiansyah, F. H. (2016). Strategi Pengembangan Peluang Peran Masyarakat dan Pemerintah Dalam Pengembangan Wisata Budaya Purbakala Situs Megalitikum di Kota Pagar Alam. Jurnal Pembangunan Wilayah \& Kota, 12(2), 169-181.

Geldern, R. H. (1982). Konsepsi tentang Negara dan Kedudukan Raja di Asia Tenggara. Translated by Deliar Noer. Jakarta: Rajawali.

Iksan, M. H. (2002). Arahan Pengembangan Wisata Megalit Di Kabupaten Lahat Provinsi Sumatera Selatan. Mini Thesis. Bandung: Universitas Islam Bandung.

Indriastuti, K. (1996). Survei Situs-Situs Megalitik di Kabupaten Lahat Provinsi Sumatera Selatan. Research Report. Palembang: Balai Arkeologi Palembang.

Indriastuti, K. (2015). Seni Lukis dan Seni Gores pada Megalitik Pasemah Provins
Sumatera Selatan. Siddhayatra, 20(2), 129-141.

Irwanto, D. (2011). Belajar dari Onggokan nan Terabaikan: Strategi Pemuatan Sejarah Lokal tentang Megalitik Pasemah dalam Materi Pelajaran Sejarah di Sekolah. Paper presented at Konferensi Nasional Sejarah IX, June 5-7, Jakarta.

Meliono, I. (2011). Ethnocracy and Multiculturalism: Preliminery Study of The Cultural Aspects Besemah People at Pagaralam, Palembang. Makar: Sosial Humaniora, 15(1), 59-66.

Notosusanto, N. (1978). Masalah Penelitian Sejarah Komtemporer (Suatu Pengalaman). Jakarta: Yayasan Idayu.

Schmoll, G. A. (1977). Tourism Promotion. London: Tourism International Press.

Sudaryadi, A. (2016). Penyelamatan Arca-arca Megalitik Situs Padang Perigi Kabupaten Lahat. Siddhayatra, 21(1), 13-23.

Sukmaratri, M. (2018). Kajian Objek Wisata Sejarah Berdasarkan Kelayakan Lanskap Sejarah di Kota Palembang. Jurnal Plano$\log i, 15(2)$.

Suryanegara. A. E. (2007). Artefak Purba Pasemah: Analisis Ungkap Rupa Patung Megalitik di Basemah. Journal of Visual Art and Design, 1(1), 128-151.

Suryanegara. A. E. (2016). Pasemah Visual Arts: Diversity of Shapes and Postures of Statues. International Journal of History and Cultural Studies (IJHCS), 2(2), 3849.

Suryanegara. A. E. (2017). Pasemah Scultures: Monuments of the Existence and Worship of Ancestors Spirit. Global Journal of Arts, Humanities and Social Sciences, 5 (1), 23-36.

Susyanti, D. W. (2014). Potensi Desa Melalui Pariwisata Pedesaan. Epigram, 11, (1), 65-70.

Swesti, W. (2019). Dampak Pariwisata terhadap Kondisi Sosial Budaya Masyarakat di Banda Aceh. Jurnal Kepariwisataan Indonesia, 13(2), 49-65.

Tim Peneliti Balai Arkeologi Pusat dan Palembang. (1992). Eskavasi dan Survei Situs Jarai/Pagaralam Kabupaten Lahat Provinsi Sumatera Selatan. Research Report. Palembang: Departemen Pendidikan dan Kebudayaan Bagian Proyek Penelitian Purbakala Palembang.

Triwurjani, R. R. (2014). Arca Perempuan dan Arca Laki-Laki Pada Kelompok Arca Megalitik Pasemah, Sumatera Selatan: 
Perspektif Gender. Forum Arkeologi, 27 (3), 35-46.

Turner. (1994). Environmental Economic: An Elementary Introduction. London: Centre For Social and Economic Research On The Global Environment University of East Angalia And University College.
Wiyana, B. (1996). Survei Situs-situs Megalitik di Kabupaten Lahat Provinsi Sumatera Selatan. Research Report. Palembang: Balai Arkeologi Palembang.

Yoeti, O. A. (2008). Ekonomi Pariwisata. Jakarta: Kompas. 